\title{
NOTES ON AUSTRALASIAN ORCHIDS 6: A NEW SPECIES OF RHIZANTHELLA (DIURIDEAE, SUBTRIBE PRASOPHYLLINAE) FROM EASTERN AUSTRALIA
}

\author{
Mark A. Clements ${ }^{1,2,4} \&$ David L. Jones ${ }^{3}$ \\ ${ }^{1}$ Australian National Herbarium/Centre for Australian National Biodiversity Research, \\ CSIRO Plant Industry GPO Box 1700 Canberra, ACT 2601, Australia \\ ${ }^{2}$ Australian National Botanic Gardens, GPO Box 1777 Canberra, ACT 2601, Australia \\ ${ }^{3}$ Kalaru, New South Wales 2550, Australia \\ ${ }^{4}$ Corresponding author: mark.clements@csiro.au
}

\begin{abstract}
AвSTRACt. Rhizanthella speciosa, a new species of the remarkable Australian underground orchids, is described as new from New South Wales. The new species, which is morphologically distinct and apparently also genetically distinct from its congeners and strikingly beautiful with its sea-anemone-like flowerheads and prominent attenuate sepals, grows in a different habitat than its geographically closest relative.
\end{abstract}

KEY WoRDs: Australian orchid flora, New underground orchid, Orchidoideae, Rhizanthella speciosa

Introduction. Rhizanthella R.S.Rogers is an enigmatic genus of orchids that created astonishment in the botanical world when it was described in 1928 by the Adelaide-based botanist Dr. R. S. Rogers using specimens discovered by a Western Australian farmer while clearing native vegetation that was dominated by a shubby myrtaceous species known as Broombush (Melaleuca uncinata) (Rogers 1928). This was followed in 1932 when a second species of underground orchid was discovered in eastern Australia, this time by Ernest Slater while digging up plants of another orchid, a species of Dipodium, on the lower western slopes of Alum Mountain at Bulahdelah in central New South Wales. This species was described by the Rev. H. M. R. Rupp in 1932. Rupp named the species after its discoverer but distinguished it from Rhizanthella, placing it in the newly erected genus Cryptanthemis Rupp. The differences between the two genera were relatively minor and a later study showed that both species belonged in the same genus, with Rhizanthella being the earlier name (Clements \& Cribb 1984).

Commonly known as the Underground Orchids because of their completely subterranean habit, this endemic Australian genus currently comprises four species, namely $R$. gardneri R.S.Rogers and the recently segregated $R$. johnstonii K.W.Dixon \& Christenh. (Dixon \& Christenhusz 2018) from the south-west of Western Australia, and two from eastern
Australia $-R$. slateri (Rupp) M.A.Clem. \& P.J.Cribb from the central coast of New South Wales and $R$. omissa D.L.Jones \& M.A.Clem. which is known from a single collection in the Lamington National Park in the Border Ranges of south-eastern Queensland (Jones $\&$ Clements 2006). Here we report on a fifth species that was recently discovered in the Barrington Tops National Park of north-eastern New South Wales.

The new species was discovered by Maree Elliot in 2016 while studying the biological diversity in the forests of the Barrington Tops National Park. An inflorescence of the Rhizanthella was uncovered whilst she was looking for native truffles as subjects to illustrate for her $\mathrm{PhD}$ on Mycological art-scientific drawing. This Rhizanthella was growing under deep leaf litter in wet-sclerophyll forest dominated by Eucalyptus saligna, a habitat which differs fairly significantly from the drier open forest habitat on Alum Mountain where an extensive study of $R$. slateri had been undertaken as part of the Pacific Highway Bulahdelah Bypass project. Comparisons between the two habitats were made and on a subsequent visit to the site in the Barrington Tops a second inflorescence of the new species was located and material collected for DNA analysis and morphological comparison with other species. Because of the significance of this discovery, the New South Wales National Parks and Wildlife Service undertook to protect the site, survey 
for more plants and study its biology, all essential data for the protection and long-term conservation of the species.

Results from this survey coupled with our own morphological studies plus preliminary results from a comparative molecular analysis confirms the distinctiveness of the Barrington Tops taxon and it is here described as new.

\section{TAXONOMIC TREATMENT}

Rhizanthella speciosa M.A.Clem. \& D.L.Jones, sp. nov. (Fig. 1-6).

TYPE: Australia. New South Wales: North Coast; Barrington Tops National Park (exact locality withheld for conservation reasons), 23 Oct. 2019, M.A.Clements 12445, P. Hillier, W.M.Dowling \& A.M.Mackenzie (holotype CANB; isotype NSW).

DiAgNosis: With affinity to Rhizanthella slateri (Rupp) M.A.Clem. \& P.J.Cribb but differing by its larger carinate floral bracts ( $c a .16 \mathrm{~mm}$ long, $c a .7 \mathrm{~mm}$ wide), bright mauve to pinkish-purple flowerheads each containing 15-35 flowers, larger flowers $(9-11 \mathrm{~mm}$ long, $c a .5 \mathrm{~mm}$ across), larger tepals (7-9 mm long) with long drawn-out filamentous tips, widely divergent lateral sepals, a larger dark purple-black, densely papillate labellum strongly folded along the midline and narrower pink to light maroon drupes.

Rhizomes and flower stems probably similar to those of $R$. slateri. Flowerheads $15-30 \mathrm{~mm}$ wide, flattish, fleshy. Sterile sheathing bracts surrounding flowerhead imbricate, 16-18, ovate-triangular, carinate, 10-12 $\mathrm{mm}$ long, 3-4 mm wide, fleshy, 1-veined, tapered to long-attenuate acuminate apex, drab white, becoming purplish on exposure. Floral bracts subtending flowers triangular, ca. $16 \mathrm{~mm}$ long, $c a .7 \mathrm{~mm}$ wide, fleshy, translucent, 1-veined, tapered to subacute apex. Flowers 15-30 per head, tubular but opening widely, 9-11 mm long, ca. 5 $\mathrm{mm}$ wide, the dorsal sepal and petals similar in shape, lateral sepals dissimilar to them, all tepals with drawn-out filamentous tips, translucent creamy white, maturing bright mauve to pinkish-purple, the flowers remaining in close proximity during anthesis, the labellum protruding between the divergent lateral sepals. Floral bracts closely sheathing ovary, triangular, carinate, $c a .16 \mathrm{~mm}$ long, $c a .7 \mathrm{~mm}$ across. Ovary narrowly cylindric, slightly wider near apex, at anthesis 7-10 mm long, 2.0-2.5 mm wide. Sepals free. Petal bases fused with column margins. Dorsal sepal narrowly elliptical, ca. $9 \mathrm{~mm}$ long, $2.0-2.2 \mathrm{~mm}$ wide, translucent with purple flecks, surface strongly wrinkled/papillate, apex attenuate. Lateral sepals widely divergent, $c a .9 \mathrm{~mm}$ long, 1.8-2.2 $\mathrm{mm}$ wide, asymmetric, broadly triangular in proximal half, shallowly curved, inner surface rugose, suddenly tapered near middle to long, thin, attenuate or filamentous apex, translucent with purple marks. Petals ca. $7 \mathrm{~mm}$ long, $2 \mathrm{~mm}$ wide, asymmetric, oblong to elliptical with short, linear, attenuate apex, translucent with purple streaks. Labellum hinged to apex of column foot by narrow claw $c a .0 .6 \mathrm{~mm}$ long; lamina strongly folded along the midline to form a deep channel, shallowly curved in profile, V-shaped in cross-section, broadly heart-shaped when flattened, $c a .4 \mathrm{~mm}$ long, $c a .3 \mathrm{~mm}$ wide, thick, fleshy, dark purple-black with paler narrow central channel, surface and margins densely papillate, apex paler and less papillate, shortly tapered, subobtuse. Column erect, much longer than wide, ca. $4 \mathrm{~mm}$ long, $c a .1 \mathrm{~mm}$ wide, translucent white with purple markings, anterior surface dark purple, apex of column narrowed, extending just above the anther; column wings narrow, $c a .0 .5 \mathrm{~mm}$ long, flanking the anther. Anther cap ca. $1 \mathrm{~mm}$ long, erostrate. Stigma cordate, $c a .0 .7 \mathrm{~mm}$ long, $c a .0 .5 \mathrm{~mm}$ wide, separated from anther by a large rostellum. Pollinarium ca. $0.4 \mathrm{~mm}$ across; pollinia bright yellow, incoherent. Drupes fleshy, narrowly cylindrical, slightly angular from compression, pinkish to light maroon when ripe. (Fig. 1-5).

FLowering: October to early November.

Distribution: Known only from a relatively small area within the Barrington Tops National Park of northern New South Wales, aprox. $470 \mathrm{~m}$ in elevation.

HABITAт: Grows under deep surface litter in tall wet sclerophyll forest dominated by Sydney Blue Gum (Eucalyptus saligna $\mathrm{Sm}$.), Tallowood (E. microcorys F.Muell.) and Turpentine (Syncarpia glomulifera (Sm.) Nied.) with a well-developed rainforest midstorey including Tree Heath (Trochocarpa laurina (Rudge) R.Br.) and Scentless Rosewood (Synoum glandulosum 

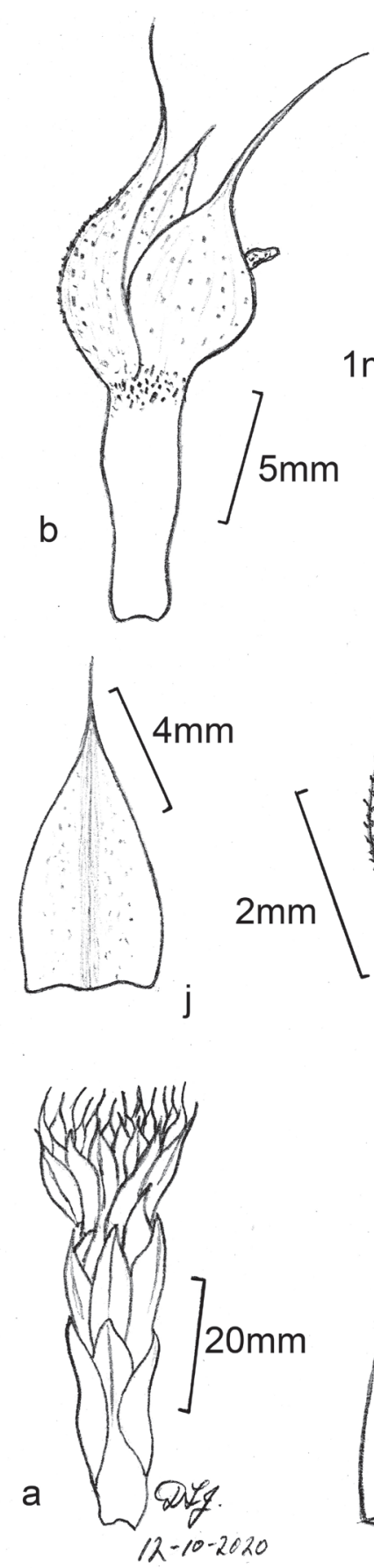
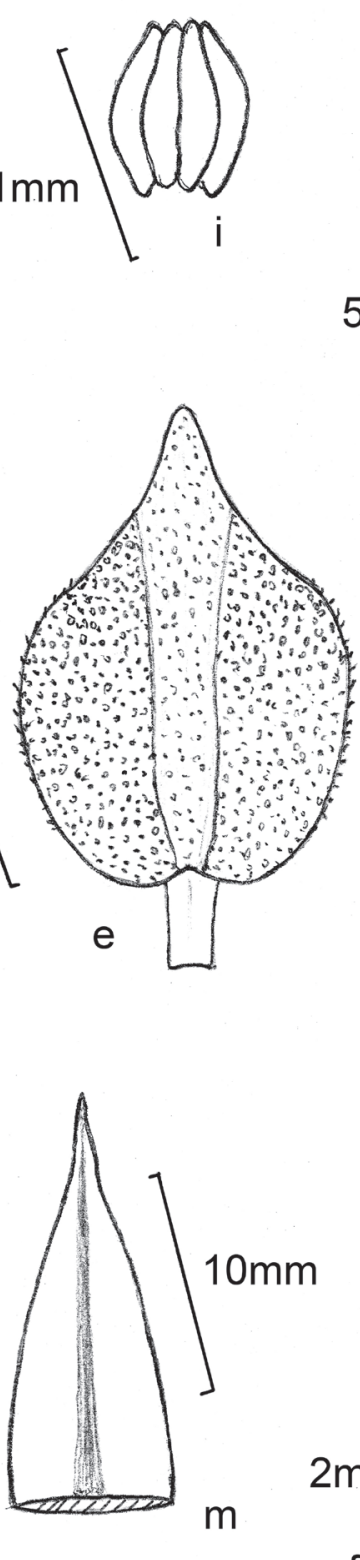
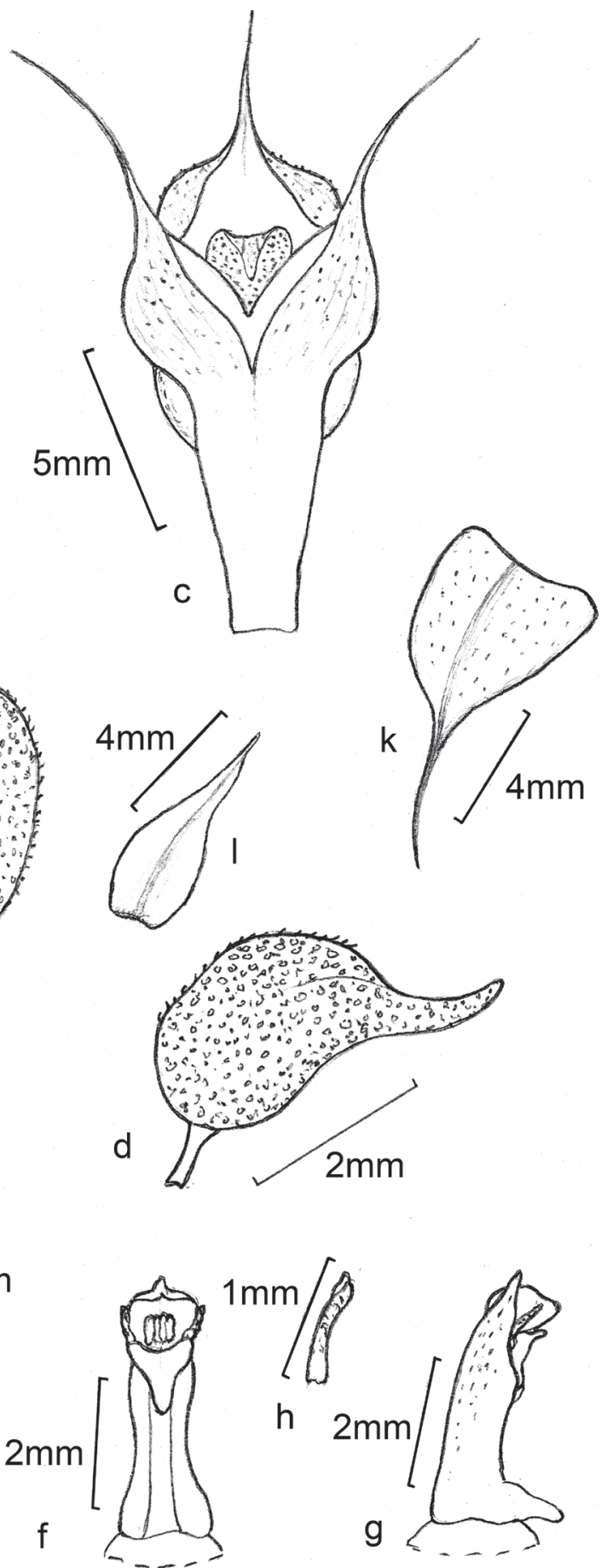

FIgURE 1. Rhizanthella speciosa, Barrington Tops, NSW, W. Dowling (DC1705). A. Stem and flowerhead. B. Flower from side. C. Flower from front. D. Labellum from side. E. Flattened labellum from above. F. Column from front. G. Column from side. H. Column wing. I. Pollinarium. J. Dorsal sepal. K. Lateral sepal. L. Petal. M. Floral bract. (Drawn from the holotype). Illustration by D.L.Jones(C), 12-10-2020. 


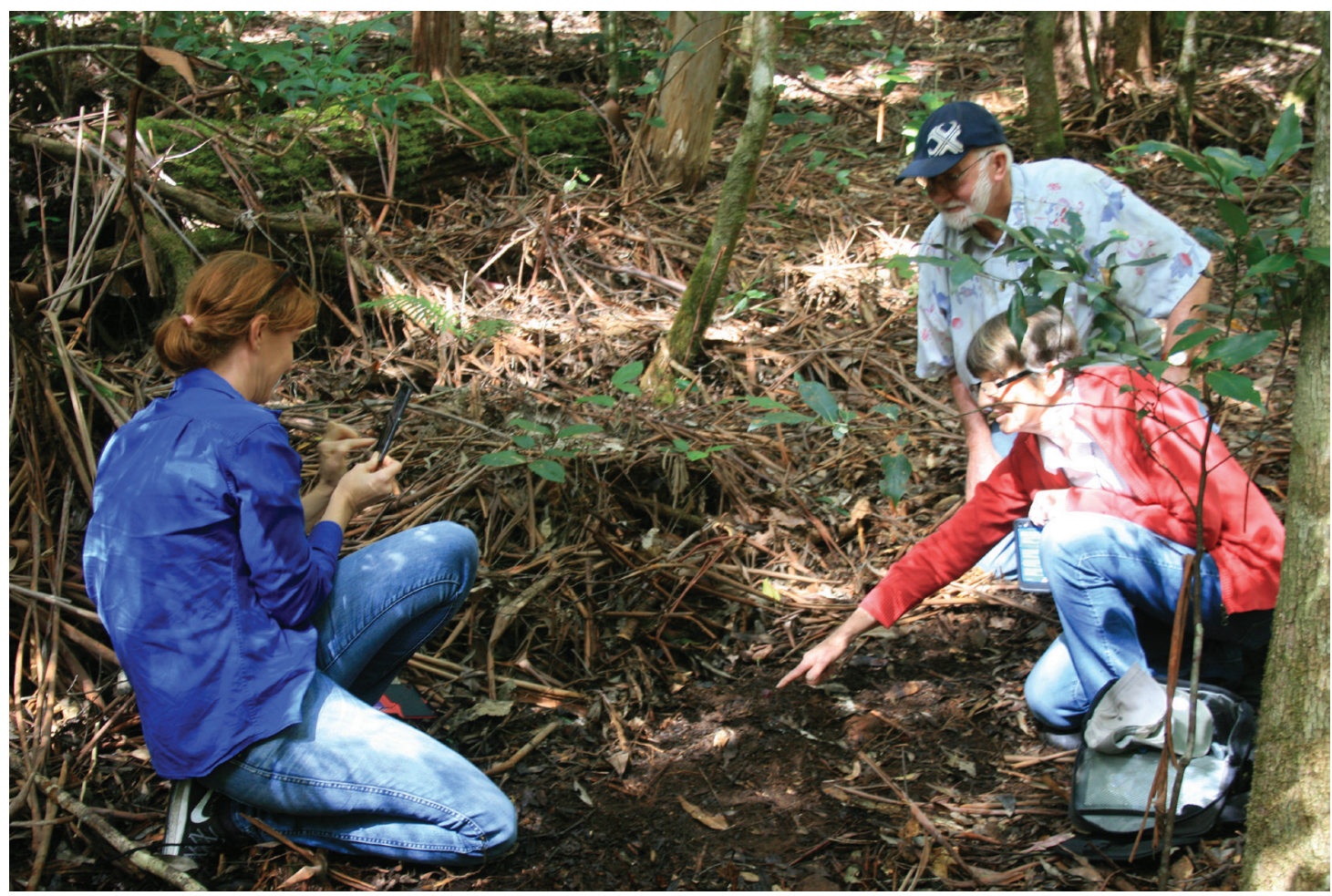

FIgURE 2. Habitat and original place of discovery of Rhizanthella speciosa with its discoverer Maree Elliot pointing to the location of one flowering head, accompanied by Sky Moore and Bill Dowling.

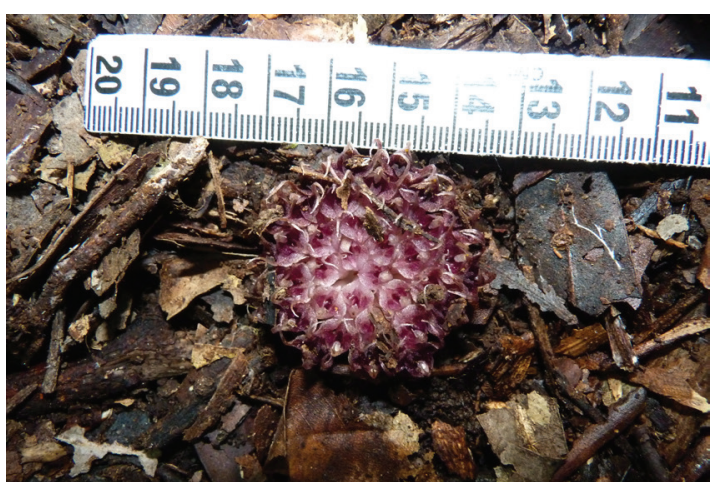

FIGURE 3. Flowering plant in situ with scale.

(Sm.) A.Juss.) and a sparse ground layer in dark clayloam over metasediments.

ReCOGNITION: This new species has large carinate floral bracts ( $c a .16 \mathrm{~mm}$ long, $c a .7 \mathrm{~mm}$ wide) that subtend the flowers and bright mauve to pinkish-purple flowerheads, each head 9-11 $\mathrm{mm}$ long and $c a .5 \mathrm{~mm}$ across and bearing 15-35 flowers. The widely-opening flowers have purple-marked tepals 7-9 $\mathrm{mm}$ long with long drawn-out filamentous tips and a dark purple-

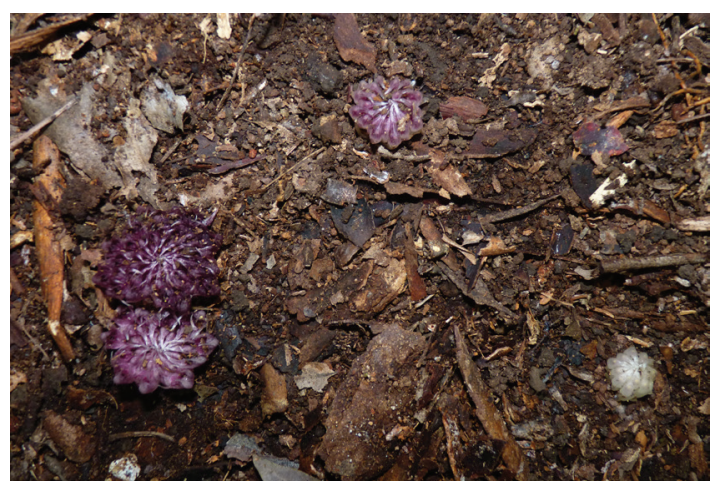

FiguRE 4. A cluster of 4 flowering heads.

black, densely papillate labellum $c a .4 \mathrm{~mm}$ long and $c a$. $3 \mathrm{~mm}$ across that is strongly folded along the midline to form a deep channel and broadly heart-shaped when flattened. At anthesis the lateral sepals diverge widely and the flowers emit an unusual animal- or fungal-like smell. The ripe drupes of this new species are pinkish to light maroon.

SIMILAR SPECIES: The new species is geographically closest to $R$. slateri and although both species have 


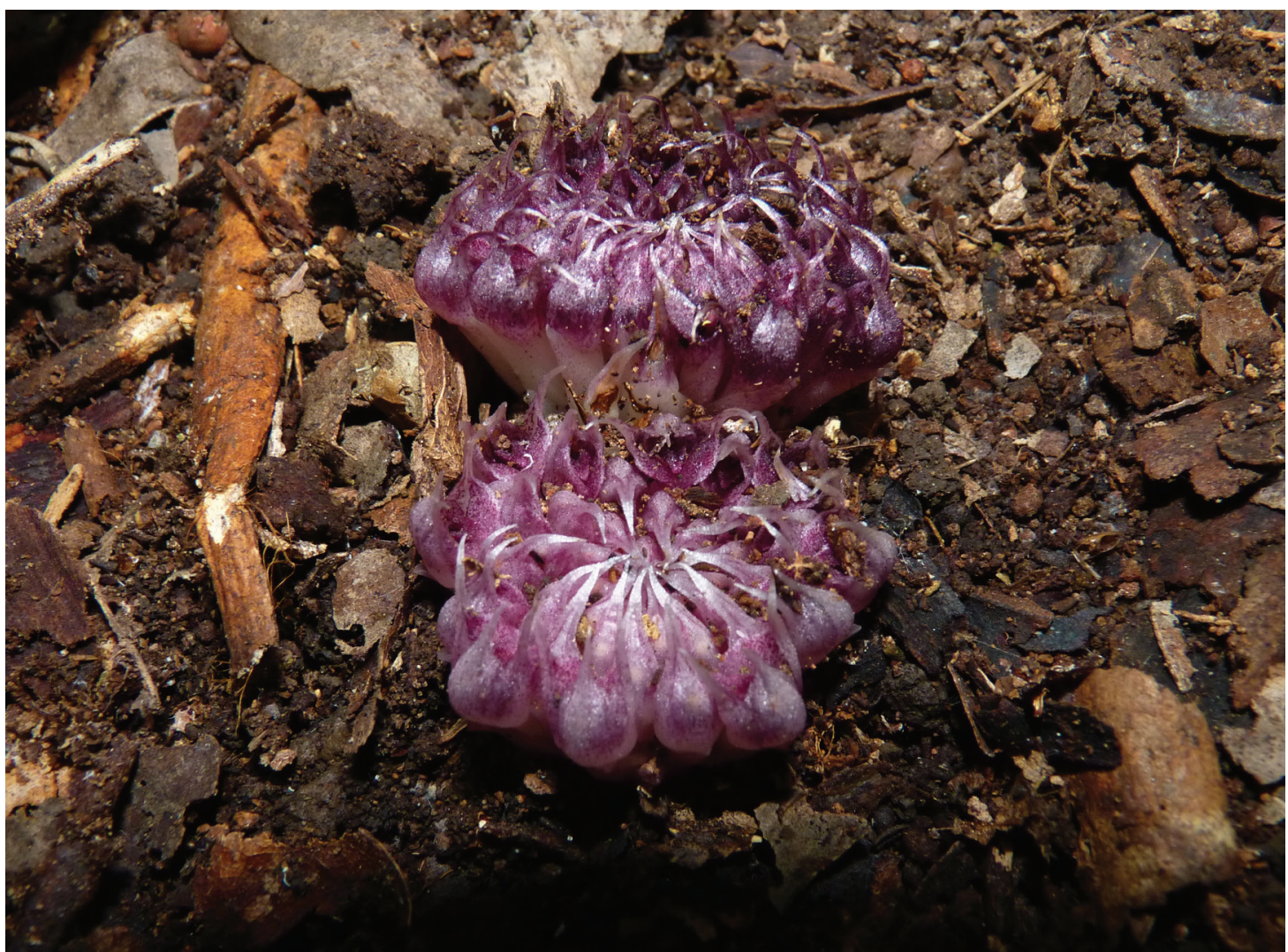

FIGURE 5. Close up of twin inflorescence one of which was collected and was used as type for the new species.

similar growth and floral features they are readily distinguished by a number of characters. By contrast to the new species, $R$. slateri has smaller floral bracts (ca. $7 \mathrm{~mm}$ long, $3 \mathrm{~mm}$ wide) and pink to dark reddish flowerheads, each head with 15-30 flowers which are $6-8 \mathrm{~mm}$ long and $c a .3 \mathrm{~mm}$ across. The flowers have densely papillate tepals $2-4 \mathrm{~mm}$ long with short extended tips and a flat, dark red, broadly heart-shaped papillate labellum $c a .2 \mathrm{~mm}$ long and $2 \mathrm{~mm}$ wide, with a smooth base. At anthesis the lateral sepals remain in close proximity and no scent is obvious. Ripe drupes are yellow.

When viewed uncovered in the wild, Rhizanthella speciosa is the most striking species found so far in the genus. The flowering head, which ranges from bright mauve to pinkish-purple in bud and in flower, is clearly visible against the dark ground and leaf litter on the forest floor. The prominent elongate sepals, which are a notable feature of this new species, give flowering plants a similar appearance to that of a sea anemone. At anthesis the flowers open widely with the lateral sepals widely divergent. In this state many inflorescences emit a pungent odor not unlike native animal faeces or a fruiting fungus. Not all flowers of the new species set fruit which contrasts with the pollination biology of $R$. slateri where a very high proportion of flowers set fruit.

Aside from the stated morphological differences between $R$. speciosa and $R$. slateri, preliminary results from a comparative molecular analysis of the two species suggest they have been separated for a long period. More study is required to determine these relationships (Katharina Nargar pers. com.). Thirtynine inflorescences were uncovered in 2019 and their position recorded. Several flowering heads, two with fruits attached were also uncovered.

Eтymology: The Latin speciosus (showy, splendid) in reference to the striking and colourful inflorescences of this species when compared to all other species of Rhizanthella. 


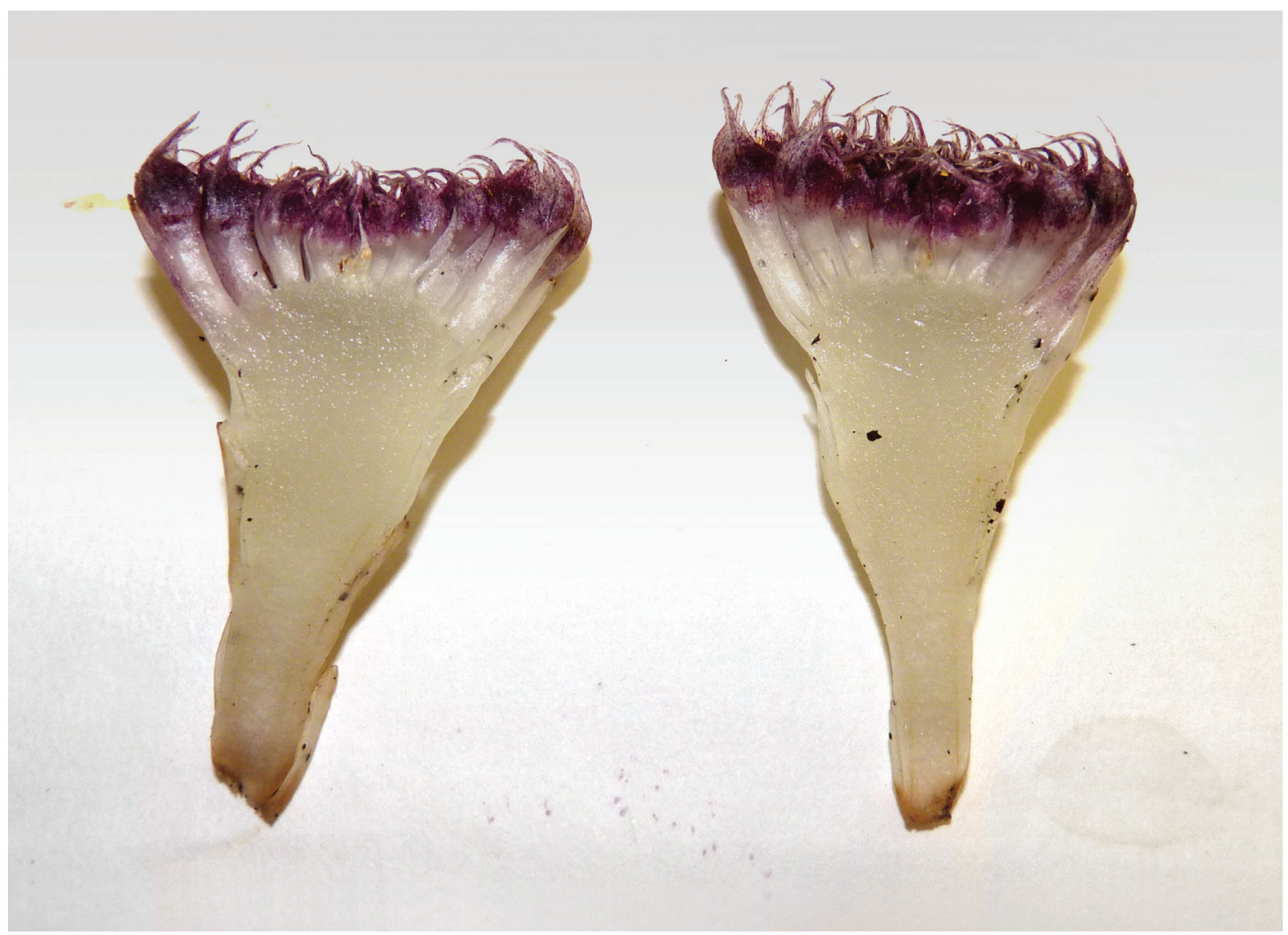

FIGURE 6. Dissected inflorescence and type of Rhizanthella speciosa.

Conservation status: Known from a single restricted but limited searching to date has failed to locate further site but conserved in the Barrington Tops National Park. populations. More field searching is required but with The habitat where it grows is a very widespread and less than 50 plants known from a single locality it meets common community in north-eastern New South Wales the IUCN criteria for critically endangered.

\section{KEY TO SPECIES OF RHIZANTHELLA}

1. Capitulum shaped like a tulip flower, sheathing bracts 3-7-veined, extending well above the flowers, tepals fused in the proximal half of the flower (western spp.)

1a. Capitulum shaped like a sea anemone, sheathing bracts 1-veined, not extending above the flowers, tepals free (eastern spp.)

2. Sheathing bracts 3 -veined, up to 100 flowers or more per capitulum, flowers pinkish red to deep red and cream

R. gardneri

2a. Sheathing bracts 3-7-veined, up to 60 flowers per capitulum, flowers white with pinkish red markings

R. johnstonii

3. Sheathing bracts $7-8 \mathrm{~mm}$ long, sepals $3-4 \mathrm{~mm}$ long with an apical point $0.5-1.5 \mathrm{~mm}$ long

R. slateri

3a. Sheathing bracts $16-18 \mathrm{~mm}$ long, sepals $6.5-10.0 \mathrm{~mm}$ long with an apical point 3-5 $\mathrm{mm}$ long

4. Apex of lateral sepals caudate, densely papillate, labellum narrowly elliptical, dark red without pale central band, margins with numerous short siliceous trichomes

R. omissa

4a. Apex of lateral sepals filiform, smooth, labellum cordate, dark purple-black with pale central channel, margins with few short siliceous trichomes

R. speciosa 
AcKnOwledgements. We thank Maree Elliot who discovered the new species and brought it to our attention; also Sky Moore and Allison Webb who assisted in this process. Paul Hillier, Senior Project Officer (Saving our Species), Biodiversity Conservation Division, Department of Planning, Industry and Environment. Liam Banyer and Aaron Mulcahy are thanked for their ongoing support, protection and study of the species. Bill Dowling provided hospitality and regular field assistance. Catherine Busby and Anne Mackenzie are thanked for their ongoing support and assistance in the field. Lachlan Copeland provided habitat details, photographs and critically checked this manuscript, and Barbara Jones read the manuscript.

\section{LiTERATURE CITED}

Clements, M. A. \& Cribb, P. J. (1985). The underground orchids of Australia. The Orchadian, 8(4), 86-90.

Dixon, K. W. \& Christenhusz, M. J. M. (2018). Flowering in darkness: a new species of subterranean orchid Rhizanthella (Orchidaceae; Orchidoideae; Diurideae) from Western Australia. Phytotaxa, 334(1), 75-79.

Jones, D. L. \& Clements, M. A. (2006). Rhizanthella omissa, a new species of Underground Orchid from south eastern Queensland. The Orchadian, 15(3), 131-133.

Rogers, R. S. (1928). A new Genus of Australian Orchid. Society of Western Australia, 15, 1-7.

Rupp, H. M. R. (1932). Notes on New South Wales orchids, II. Proceedings of the Linnean Society of New South Wales, 57, 57-61. 
